\title{
DEVELOPING INFORMATION TECHNOLOGY LAW AND LEGISLATION: ANALYSIS OF INTERNATIONAL EXPERIENCE AND POSSIBILITIES OF ITS APPLICATION IN UKRAINE
}

DESARROLLO DE LEYES Y LEGISLACIÓN SOBRE TECNOLOGÍAS DE LA INFORMACIÓN: ANÁLISIS DE LA EXPERIENCIA INTERNACIONAL Y LAS POSIBILIDADES DE SU APLICACIÓN EN UCRANIA

\author{
Irina Aristova* \\ Oksana Brusakova** \\ Denis Koshikov ${ }^{* * *}$ \\ Oleksandr Kaplya****
}

\begin{abstract}
The purpose of this article is focusing attention on the relevant problematic issues that exist in the sphere of legal regulation of domestic area of high technologies, as well as finding ways of their effective solution. Noted that the legal regulation of objects and phenomena surrounding the domestic information technology (IT) sphere is quite weak and insufficient compared to other countries. Effectively functioning practices of legal
\end{abstract}

\footnotetext{
* Doctor of Law. Professor. Head of the Department of Administrative and Information Law, Sumy National Agrarian University (Sumy, Ukraine). https://orcid.org/0000-00019211-3464. aristova07@gmail.com

** Doctor of Law. Associate Professor. Dean of the Faculty No. 6 of Kharkiv National University of Internal Affairs (Kharkiv, Ukraine). https://orcid.org/0000-0001-8616-0424. advokat.brusakova@gmail.com

*** Candidate of Jurisprudence. Senior Lecturer of the Department of Police Activity and Public Administration of the Faculty No. 3 of Kharkiv National University of Internal Affairs (Kiev, Ukraine). https://orcid.org/0000-0002-2546-0965. besolgigo@ gmail.com **** Doctor of Law. Professor of the Department of Law Enforcement and Anti-Corruption Activities of the Educational and Scientific Institute of Law (Kiev, Ukraine). Senior Researcher at Interregional Academy of Personnel Management (Kiev, Ukraine). https://orcid.org/0000-0001-8629-0771. kaplia.oleksandr@gmail.com
} 
regulation of the sphere of high technologies that exist in developed democracies are analyzed for their compliance with the realities of the domestic legal system. Considerable attention is paid to the characteristics of the current state of functioning of IT law and legislation in democracies. The initial successes that have already been achieved in Ukraine in relation to the IT sphere in the past were analyzed. The perspective directions of further development of IT law, as well as related domestic and international legislation, are considered. It is pointed out that the development of both the domestic high-tech industry and the functioning of IT law and legislation are inextricably linked with the democratization of the country. The methodological basis for writing the article was a set of general scientific and special methods and techniques of scientific knowledge.

Keywords: Information Technology Law, High Technologies, Systemic Reform, High-Tech Industry, Legislative Support

Resumen: El propósito de este artículo es centrar la atención en las problemáticas relevantes existentes en la regulación legal nacional de las altas tecnologías, así como encontrar vías para su efectiva resolución. En este sentido, se evidencia que la reglamentación de los objetos y fenómenos que rodean la esfera de TI (tecnologías de la información) es bastante débil $e$ insuficiente en comparación con otros países. Se analizan las prácticas regulatorias en relación con las altas tecnologías cuyo funcionamiento resulta eficaz en las democracias desarrolladas, con la finalidad de analizar su adecuación a las realidades del ordenamiento jurídico ucraniano. Se presta especial atención a las características del estado actual de funcionamiento de la legislación sobre tecnologías de la información y las comunicaciones en la esfera democrática. Se analizaron los éxitos iniciales logrados en Ucrania con respecto a las tecnologías de la información en el pasado. A su vez, se consideran las direcciones de perspectiva de un mayor desarrollo de la legislación sobre tecnologías de la información, así como la legislación nacional e internacional relacionada. Como conclusión, se señala que tanto el desarrollo de la industria nacional de alta tecnología como el funcionamiento de la ley y la legislación sobre tecnologías de la información están indisolublemente vinculados con la democratización del país.

Palabras clave: Derecho de las tecnologías de la información, altas tecnologías, reforma sistémica, industria de la alta tecnología, apoyo legislativo 
Summary. I. Introduction. II. Methodology of the Study. III. Analyzing the Results and Findings for a Prospective Application of Information Technology Laws in Ukraine. IV. Conclusions. References.

\section{INTRODUCTION}

There is no society without information, as there is always that necessity to communicate. The modern society necessitates the introduction of new information technology (IT) solutions to meet its needs. With the spread of know-how, the need for its detailed analysis with the further determination of the direction of development. In the context of globalization, modern society is developing rapidly. Today's challenges are related to the increase of human needs, which in turn determines the desire to ensure their dynamic and high-quality satisfaction. Therefore, there is an urgent need to modernize (Gramatskyy, et al., 2020).

Nowadays, it is quite literally to say that the high technology sector is one of the most important and rapidly changing areas of public life. The global high-tech sector accumulates a significant amount of financial, monetary and other resources among other things. It is also recognized as having a significant impact on almost all areas of the development of both public and private sectors. A bright example to confirm this thesis is the fact that high technology has changed the world around us very rapidly and irreversibly, thus affecting the surrounding society. This factor has become especially significant during the world pandemic-Covid 19, because people increasingly buy everything in online stores at this time, and much of the business environment has transferred their employees to a remote way of working. The progress of science and technology has implications for the progress of the current trading method. It is not only done conventionally but also carried out through cyberspace. Trading in the virtual world requires the use of a domain name (cyber-squatting) as a differentiator between one company with other companies (Dharma, 2014). As a result, the role and importance of IT law and legislation in this area has significantly increased.

According to the general views of researchers, the development of IT law in Ukraine, which regulates all relations within and around the high technology sector, has not reached the high efficiency of its operation in developed Western countries and some Asian countries yet. While legal regulation of the high-tech sector in developed countries helps both individuals and the State to receive significant profits and benefits, Ukraine still suffers from poor legal regulation of these processes. The modern system of ensuring information security and cybersecurity in Ukraine should 
be one effective system, consisting of such mandatory components as legal, educational and technical (Kazanchuk \& Yatsenko, 2020). Therefore, given the high relevance of this topic both in Ukraine and in most countries around the world, experts pay close attention to the issues covered in this article, as well as look for the ways to effectively solve them.

\section{METHODOLOGY OF THE STUDY}

The following methods were used to conduct the study. The dialectical method was used to describe the legal regulation of public relations associated with the development of IT law, as well as to overcome the contradictions between past norms and the need to improve them. The systematic method made it possible to characterize the existing limits of legal regulation of public relations associated with the development of IT law, in their relationship with the norms of other legal institutions, including international law. The structural method was useful for characterizing the construction of rules governing international standards of legal regulation of public relations related to the development of IT law. Moreover, the formal legal method allowed the authors to analyze the importance of legal norms in the field of international standards of legal regulation of public relations related to the development of IT law, to interpret them from the point of view of formal legal logic. Deduction helps to explore the relationship between international change and its implementation. With the help of induction, the influence of negative phenomena in the field of legal regulation of IT law has been studied.

\section{ANALYZING THE RESULTS AND FINDINGS FOR A PROSPECTIVE APPLICATION OF INFORMATION TECHNOLOGY LAWS IN UKRAINE}

The extremely rapid development of an information-aware society requires the effective regulation of the State policy in the field of combating cybercrime. The rapid development of technology creates new opportunities in the use of information space, but new opportunities entail new threats in this area (Didenko, 2020). New ways of transmitting information appear, new ways of communication between people are created with the development of social relations, science, technologies. Virtual environment, Internet network, cyberspace - these are the terminological concepts that characterize the new opportunities and define their special, characteristic 
type of social relations. We have witnessed the formation of special relationships between people that differ from the real ones (Novitskyi, 2017, p. 136). Peculiarities of information and technological relations determine that they will always be ahead of the legislative process due to the intensity of their development. In this regard, the construction of the system of sources of their legal regulation should be aimed at overcoming possible gaps, on the one hand, and allow the participants in these relations to independently regulate their relations in accordance with the general principles of law, on the other hand (Pozova, 2017).

As of today, we can confidently state that the domestic sphere of legal regulation of public relations related to the high-tech industry is in dire need of the development and fundamental improvement in accordance with the current situation in this sphere. Therefore, we argue that based on the results of scientific research conducted by both domestic and foreign scientists, it is hardly possible to even use the term of "legal regulation of the IT sphere" in Ukraine as of 2021, because it still does not exist as a single system among other legal relations (Chandra, 2019). Part of the guilt is common to relate with those domestic politicians and lawyers, who instead of working in a coordinated and systematic manner to create a single mechanism of legal acts regulating the high technology sector, passed individual and unrelated laws. In addition, such individual laws were adopted not so much to qualitatively reform and address the above problems, but to promote the interests of specific individuals over the interests of society in the whole (Dar, et al., 2021). On this basis, the state has such consequences, which are weak and frankly inadequate legal regulation of the high-tech sector. In turn, this state of affairs leads to the fact that the underdevelopment of the legal sphere surrounding the high-tech sector of the economy does not allow Ukraine and its citizens to fully develop and make profits (Joseph \& Ray, 2020).

Having studied the practical experience of legal regulation of high technology sector in the developed Western countries, we should note the high benefits and efficiency that it creates. First of all, it is applied to the extremely high revenues that the IT industry brings to the state and local budgets of these countries, as well as to a wide range of related citizens and organizations.

Specifying and revealing the above statement in a broader form, we state on the basis of the results of recent research that the economies of Western countries, especially the economy of the United States, really thrive on how effectively and harmoniously they govern the legal regulation of high-tech sector (Kemp, 2020). Of course, given the fact that the United States is administratively divided into 50 separate states, where each state has its own legislation and its own specific rules and standards for doing 
business, the levels of the IT sector's development, as well as the levels of profits derived from it, are seriously different. However, the vast majority of states are characterized by ease of doing business for individuals and legal entities in general, the ability to quickly set up a business or organization, and the possibility of their immediate official liquidation for one reason or another (Palker, 2019). All this, as noted by many researchers, is recognized possible due to a high-quality, systematic and careful approach to the legal regulation of high technology sector. Thus, it is the very thing and characteristic feature of American life that Ukraine currently lacks. And it concerns not only the IT sector, but also other industries.

The situation with the legal regulation of the high-tech sector in the countries of Western and Central Europe is also recognized as quite successful and effective. But the revenues of European countries from the IT sphere are lower than in the United States due to some subjective reasons. This state of affairs is not the result of any mistakes or shortcomings in the legal regulation of high technology sector in European countries. Instead, as noted by foreign experts who are involved into in-depth research of these problems and issues, the problem is mostly that the majorities of the modern "giants" of the international IT society were created and operate in the United States of America.

Thus, according to the same experts, this and other circumstances, for example, the fact that European Union Member States do not have significant leading companies in the field of IT, and it leads to the fact that the lion's share of profits from IT activities is deposited in the United States (Kemp, 2019).

The specificity of the European market is that it is based not on individual "technology giants", but on the support of medium and small businesses, i.e., small and medium-sized high-tech companies, which form the basis of the European IT environment. It is the reason why the legal regulation of the high-tech sector in the countries belonging to the European Union is based on the above principle of support for medium and small companies. In particular, it creates special conditions for running a relatively small but successful IT business is much more profitable than to create a single, dominant company.

Some researchers argue that legislators and legal scholars from EU countries by following this approach, which is expressed in preventing the emergence of the European "IT giant" both in Europe and around the world, are trying to achieve greater equality in the matters on financial well-being of citizens. In other words, they pursue a special legal policy, which has the ultimate purpose to ensure that all subjects of public legal relations, which 
are related in one way or another to the high technology sector, have more equal opportunities for competition (King, 2021).

Having studied the current state of affairs in the systems of IT law of Western countries, we can state that IT law is more developed there out of all other places and regions of the world. Certain specifically developed systems currently exist in some authoritarian countries. For example, we can single out Singapore, China, the United Arab Emirates and some other countries, which still managed to create more or less comfortable conditions in the field of legal regulation, despite their undemocratic system of political power, and which in some ways facilitated the operation of various hightech companies in those countries. But at the same time, it should be noted that there are real developed democracies with real rule of law along with countries with authoritarian political systems in the regions of East Asia and the Middle East. In particular, such countries may include Japan and South Korea as developed democracies in the Far East, as well as Israel as almost the only true liberal and legal democracy in the Middle East (Simkus \& Eecke, 2020).

It has been emphasized that those countries, although relinquish to the United States and some Western European countries in the volume (size) of financial and monetary turnover in the high technology sector, but they are not worse in regard to the quality, efficiency and dynamism of the components of the IT sector. In addition, the liberal and democratic regime of the state system, effective decision-making mechanisms, the independence of the judicial system have greatly contributed and continue to contribute to the high development of the IT sphere and the surrounding IT law in those countries. For example, they were able to create a market for the IT sector in Israel, which does not relinquish to any of the modern advanced countries in its importance and development. Both the market of IT services and other components of the local high-tech sector are definitely in high demand around the world for a long period of time (Zalewski, et al., 2021; Lenoir, 2018).

It is important to emphasize that an integral part of the legal regulation of the high technology sector in the developed countries is a set of legal and other instruments through which the State represented by its competent authorities can ensure the protection of entities in this area, i.e., individuals and legal entities. In particular, it has been noted that there are first of all those ways and means among the above-mentioned instruments of influence, which assist to guarantee a proper security for all participants in legal relations in the IT sector.

Scholars of the related branches note that the high-tech sector is regulated in every country where it is more or less developed and its 
participants are protected by a reliable system of legal regulation (O'Donoghue \& O'Brien, 2021). Thus, there are powerful mechanisms for the legal protection of subjects and objects of cybersphere in the United States, which are based both on legal acts and executive orders of the powerful federal government of this state and on precedents of effective independent regulation of certain components of the IT sector at the level of certain states. Thus, the leaders in the field of efficiency of legal regulation of the functioning of the high-tech sphere among the American states are usually those where the majority of companies and enterprises involved in the production of the software, computers, etc., are located. First of all, those are states such as California, New York, Massachusetts and several other states in the North East of the United States. However, researchers claim that this list could even be called demoded from some points of view. Since more and more diverse IT startups and other high-tech companies have recently appeared in different states, many of which are involved in the advanced development of various IT components and are experiencing rapid growth (Hayes \& Watson, 2019).

With regard to Ukraine, it should be noted that the methods and concepts associated with the existence of several "centers" of legal regulation of relations in the field of high technology are not very suitable for Ukraine. Given the fact that Ukraine is partially decentralized, but still a unitary state, it needs to adopt the experience of those countries that have a similar form of administrative and territorial system and demonstrate high efficiency in the IT sector. In particular, it would be appropriate to refer to the successful experience of Israel in this context, which has already been mentioned in this article. This state, having a relatively small size of both population and territory, being unitary, nevertheless was able to become a leader in the world industry of high technology, steadily maintaining its leading position this far. It is clear that no country will be able to do without the adoption of the American experience. It is known that the vast majority of "trends" and new developments in the IT sector, as well as in the field of legal regulation and protection of IT are originated from the United States (Thompson \& Kramer, 2017).

On the example of the above-mentioned developed countries, we can state that the clarity and effectiveness of the legal system in relation to the high technology sector is the key criterion for its protection. It has been stated that direct and unambiguous acts of legal regulation, which clearly define the "rules of the game", as well as clearly prescribe the procedure and reasons for punishing the subjects, reliably protect the IT sector from various encroachments. 
It has been also added that the system of legal regulation should be comprehensive and include both the actual means of legal regulation that can clearly describe the content and essence of public legal relations arising in the field of high technology, as well as methods and means that allow entities of legal relations in this area to be protected from various illegal encroachments. It is the reason we note that such a model of the system of legal regulation of the high-tech sector should be created in Ukraine. The ways to counteract to the latest offenses in the IT sector deserve particular attention among other things. Thus, the effective counteraction and the work to prevent such illegal IT encroachments as "phishing", various types of blackmailing offenses, cyber espionage and others is recognized important (Flynn \& Day, 2021).

Given that cyberattacks have increased significantly over the last decade, especially cyberattacks from one country to another, experts from different countries have begun to accomplish certain work to improve legislation in this area. In particular, some countries have developed a set of instruments to effectively protect against cyberattacks and their consequences. For example, criminal liability has been introduced in the United States for denying participation in cyberattacks. Besides, serious attention was paid both to the instruments of prosecuting those who actually committed the crime within cyberspace and to those who helped, facilitated and were involved by other actions in the above-mentioned offenses in the IT sector. It is applied to the production and distribution of various malicious software, which is then used by individuals in committing cyberattacks. Independent researchers of these processes confirm that the abovementioned innovations in American law have significantly improved the legal regulation of public legal relations in the IT sector, as well as increased the protection of this area in the whole (Isaacs \& Margolis, 2021).

We tend to suggest that the composition of domestic systems and strategies should adopt such methods and means of legal counteraction to encroachments on the security of cyberspace, as well as effective principles of legal regulation of the activities of cyberspace entities. Accordingly, foreign legal acts, which have proved their effectiveness due to clear regulation of legal norms, should be included into domestic legislation.

\section{CONCLUSIONS}

1. Summarizing all stated above, we can confidently note that such a field of public life as IT law is certainly important and integral part of 
modern society and has all the necessary prerequisites for further active development.

2. It should be noted that there was a clear sequence between how any country is developed in the field of high technologies and between the levels of effectiveness of its legal regulation of the IT sector. We should separately emphasize that other factors may influence on the peculiarities of the development of the IT sector and IT law in the country to some extent. The political regime in the State should be singled out among them, namely, whether the fundamental principles of democracy, pluralism, liberalism and the rule of law are observed in a particular State. Or, on the contrary, the State is absorbed by an authoritarian system of government that tends to suppress individualism among its citizens, which is the driving force for technological achievements.

3. The authors of this article have definitely cited examples of several States that, despite their authoritarian political system and suppression of freedom of speech, were able to achieve the development of their own IT sector. However, we argue in this regard that, first of all, such countries should rather be recognized as an exception to the general rule. Secondly, they still lag behind the developed and democratic countries of Western Europe and North America in the quality and comprehensiveness of legal regulation of the above processes. For example, the authoritarian political system does not allow for the effective protection of all entities of legal relations, despite the fact that special legislation facilitating high-tech business promotes the overall development of the sector.

4. Thus, we state that Ukraine should follow the example of developed Western democracies in the field of IT law development. First of all, such countries are the United States, Canada and European Union Member States. Active international cooperation will help to improve the situation with IT law in Ukraine. 


\section{REFERENCES}

Chandra, A. (1-V-2019). Development in Technology and Its Impact on Law. Mondaq. https://www.mondaq.com/india/social-media/801884/development-intechnology-and-its-impact-on-law

Dar, A., Katarki, S., Viswanath, N., Suri, S., Agarwa, A., \& Ashok, A. (3-III-2021). New Rules for Digital Media Platforms and Intermediaries. Mondaq. https://www.mondaq.com/india/media-entertainment-law/1042234/new-rulesfor-digital-media-platforms-and-intermediaries

Dharma, S. (2014). Perlindungan Merek Terdaftar Dari Kejahatan Dunia Maya Melalui Pembatasan Pendaftaran Nama Domain. Jurnal Cita Hukum, 2 (2), 193-206.

Didenko, A. (2020). Purpose, Tasks and Principles of the State Policy in the Field of Combating Cybercrime. Law and Safety, 76 (1), 53-59. Doi: https://doi.org/10.32631/pb.2020.1.07.

Flynn, B., \& Day, J. (21-IV-2021). EDPB Publishes Response to European Commission on Processing Personal Data for Health-Related Research. Mondaq. https://www.mondaq.com/uk/data-protection/1059586/edpb-publishesresponse-to-european-commission-on-processing-personal-data-forhealthrelated-research

Gramatskyy, E., Kryvosheyina, I., Makoda, V., \& Panova, L. (2020). Innovation ITPayment Technologies as a Know-how and an Object of Intellectual Property Rights. Political Questions, 38 (67), 518-535.

Hayes, J., \& Watson, A. (III-2019). Facial Recognition Technology and Data Protection Law. BCL Solicitors LLP. https://www.bcl.com/facial-recognition-technologyand-data-protection-law/

Isaacs, D., \& Margolis, D. (30-IV-2021). EU Expected to Approve UK's Data Privacy Regime. JD Supra. https://www.jdsupra.com/legalnews/eu-expected-toapprove-uk-s-data-2748014/

Joseph, V., \& Ray, D. (10-II-2020). Cyber Crimes Under the IPC and IT Act. An Uneasy Co-Existence. Mondaq. https://www.mondaq.com/india/it-andinternet/891738/cyber-crimes-under-the-ipc-and-it-act--an-uneasy-co-existence

Kazanchuk, I. D., \& Yatsenko, V. P. (2020). Peculiarities of Legal Regulation of Activities of the National Police of Ukraine in the Field of Ensuring Information Security in Ukraine. Law and Safety, 79 (4), 32-38. Doi: https://doi.org/10.32631/pb.2020.4.04

Kemp, R. (2019). Legal Aspects of Managing Data. Kemp IT Law. https://www.kempitlaw.com/legal-aspects-of-managing-data/

Kemp, R. (2020). Trends in Information Technology Law: Looking Ahead to 2020. Kemp IT Law. https://www.kempitlaw.com/trends-in-information-technology-lawlooking-ahead-to-2020/ 
King, M. (26-IV-2021). Hybrid Working and Data Protection Issues - Making Sure it is Not an Achilles Heel for Organizations. Mondaq. https://www.mondaq.com/uk/data-protection/1061320/hybrid-working-anddata-protection-issues-making-sure-it-is-not-an-achilles-heel-for-organisations

Lenoir, S. (19-X-2018). Data: The Heart of the Industry of the Future. Mondaq. https://www.mondaq.com/uk/technology/747432/data-the-heart-of-theindustry-of-the-future

Novitskyi, A. M. (17-XI-2017). Guaranteeing Human Rights and Freedoms Within ITRelations. IT Law: Problems and Perspectives for the Development in Ukraine. Collection of Materials of the II International Scientific and Practical Conference. Lviv Polytechnic National University.

O’Donoghue, C., \& O'Brien, S. (5-V-2021). EDPB Clarifies the Application of The GDPR for Scientific Research. Technology Law Dispatch. https://www.technologylawdispatch.com/2021/05/privacy-dataprotection/edpb-clarifies-the-application-of-the-gdpr-for-scientific-research/

Palker, S. (5-IV-2019). Data Privacy Laws Across Latin America. TMF Group. https://www.tmf-group.com/en/news-insights/articles/2019/april/data-privacylaws-across-latin-america/

Pozova, D. D. (2017). Sources of Legal Regulation of Relations on the Internet. Časopis Civilistiki, 24, 93-96.

Simkus, A., \& Van Eecke, P. (25-XI-2020). European Union: Regulating Big Data European Commission Introduces Data Governance Bill. Cooley. https://cdp.cooley.com/regulating-big-data-european-commission-introducesdata-governance-bill/

Thompson, B., \& Kramer, J. (21-XI-2017). GDPR, Part IV: The Data Subject Consent Provisions. Lewis Brisbois. https://lewisbrisbois.com/blog/category/dataprivacy-cyber-security/gdpr-part-iv-the-data-subject-consent-provisions

Zalewski, T., Jameson, A., Wortley, W., Rivas, J., \& Lutz, F. (22-IV-2021). Artificial Intelligence and Data Sharing. Mondaq. https://www.mondaq.com/uk/dataprotection/1060384/artificial-intelligence-and-data-sharing- 